\title{
Distribution of juvenile leatherback sea turtle Dermochelys coriacea sightings
}

\author{
Scott A. Eckert* \\ Hubbs-Sea World Research Institute, 2595 Ingraham Street, San Diego, California 92109, USA
}

\begin{abstract}
Data on the location, date, sea temperature, and turtle size for 98 small $(<145 \mathrm{~cm})$ leatherback sea turtles Dermochelys coriacea demonstrate that leatherbacks less than $100 \mathrm{~cm}$ in carapace length occur only in waters warmer than $26^{\circ} \mathrm{C}$.
\end{abstract}

KEY WORDS: Leatherback · Dermochelys $\cdot$ Juvenile $\cdot$ Temperature requirements $\cdot$ Developmental habitat $\cdot$ Endangered species

\section{INTRODUCTION}

One of the great mysteries of sea turtle life history is where young turtles reside between the time they first enter the sea as hatchlings and when they return to coastal habitats as juveniles. This period can span a few to many years. Brongersma (1968) proposed that loggerhead sea turtle Caretta caretta hatchlings from US Atlantic beaches move directly offshore and, as young juveniles, reside in the pelagia passively drifting to Atlantic Europe. He proposed that after some indeterminate period they returned to benthic habitats on the US eastern seaboard. Carr (1986) provided additional evidence for this pattern of dispersal. Similar migrations have been described for the loggerhead in the Pacific (Bowen et al. 1995) and are suspected for other species, with 2 exceptions. The Australian flatback turtle Natator depressus may remain in coastal waters throughout its life (Walker \& Parmenter 1990), whereas the leatherback remains pelagic.

Despite a growing understanding of the developmental life stages and habitats utilized by the young of most sea turtle species (Musick \& Limpus 1997, van Dam \& Diez 1998), there is no information on where hatchling leatherback turtles Dermochelys coriacea go after leaving the nesting beaches (Brongersma 1970).

*E-mail: seckert@hswri.org
Deraniyagala (1936) suggested that they remain in the open ocean, based on the sighting of a juvenile $20 \mathrm{~km}$ from shore.

\section{METHODS}

There are very few records of juvenile leatherback sightings or occurrences in the scientific literature. Thus, for insights into the distribution of juvenile leatherbacks, I gathered primary material from sea turtle and marine mammal stranding coordinators, published literature, museum records and reports, and personal communications with qualified sea turtle biologists. Because such data are often gathered in a manner less rigorous than optimal, I was very careful to evaluate each report for accuracy. If there was any question as to location accuracy, size of turtle or other such information, the record was rejected from my analysis. Of particular concern was the size of the turtle, as often the data records only list estimated size, or it was unclear how size was determined. In such cases the data were rejected. Fortunately, because the morphology of the leatherback is so distinct, species misidentification was rarely a concern as it might be with other species of sea turtle. I restricted data to turtles with measured curved carapace lengths $(C C L)<145 \mathrm{~cm}$. For 2 turtles of $11.5 \mathrm{~cm}$ and $19.0 \mathrm{~cm}$ length, I accepted the straight line measure, because 


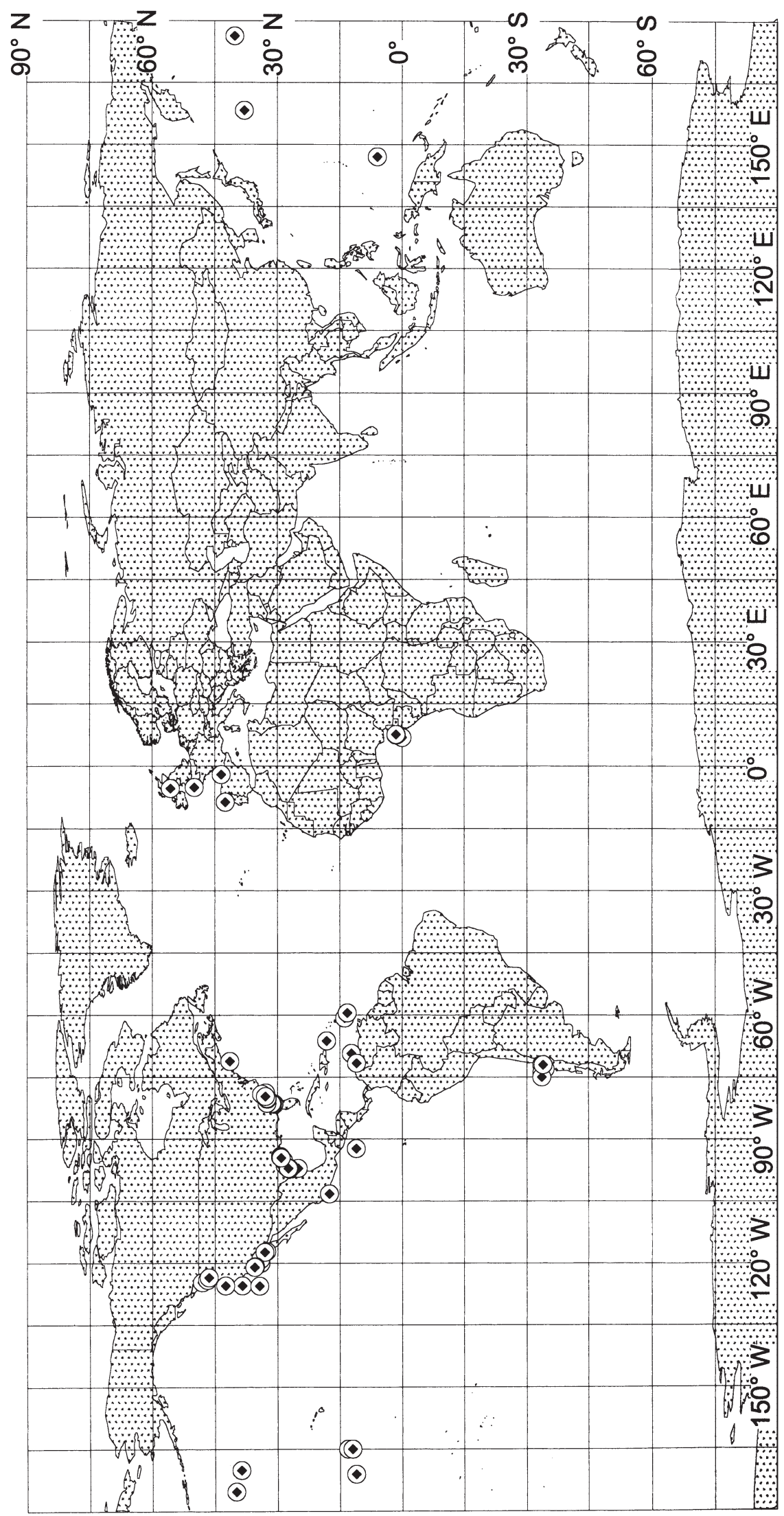


such small turtles have relatively little curvature to their carapaces and there should be little difference between the 2 measurement methods. Date, location, and water temperature (if available) were noted. If water temperature (whose accuracy could be confirmed) was not available at the location of the sighting, I used satellite sea surface temperatures (SSTs) for the time and location of the sighting (see http://podaac. jpl.nasa.gov/mcsst/). Such data are readily available on the worldwide web for the period from 1 January 1987 to 20 November 1999. For a detailed discussion of the accuracy of this information see Vazquez et al. (1998). In cases where no SST data were available on the same date as the sighting due to cloud cover or poor satellite coverage, I used the nearest good date $( \pm 4 \mathrm{~d})$.

\section{RESULTS}

One hundred records of juvenile leatherbacks qualified for my analysis. Of these, 26 were from the published literature (Brongersma 1969, 1970, 1972, Frair et al. 1972, Greer \& Wright 1973, McCoy 1974, Rhodin \& Schoelkopf 1982, Standora et al. 1984, Horrocks 1987, Johnson 1989, Frazier 1990, Eckert 1993, Sparks 1993, Acuna \& Toledo 1994, Grant 1994, Pino \& Pino 1996), 66 were from United States (State or Federal) sea turtle or marine mammal stranding network coordinators, 4 were from fishery observer records, 2 were from museum records, and 2 were from unpublished data. (Work \& Balazs unpubl., M. Stinson pers. comm.). Their latitudinal distribution extended from $56.75^{\circ} \mathrm{N}$ to $33.58^{\circ} \mathrm{S}$, with the majority of records from the Northern Hemisphere (Fig. 1). Of the records, 5 were discarded from further analysis due to their carapace size being listed as straight length. A scatterplot of the size of turtles and latitude suggested a positive and gradual increase in turtle size with increasing latitude. To confirm that this relationship was positive and statistically significant, a correlation test was conducted against Northern Hemisphere sighting data, (Pearson product-moment correlation, $\mathrm{r}=$ $0.693, p<0.05$ ). To confirm the gradual nature of the increase, size data was divided into $20 \mathrm{~cm}$ size classes and the most northern sighting of each size class was used in a linear regression analysis $(r=0.85212)$ (Fig. 2). In contrast, the relationship between juvenile leatherback distribution and water temperature was not grad-

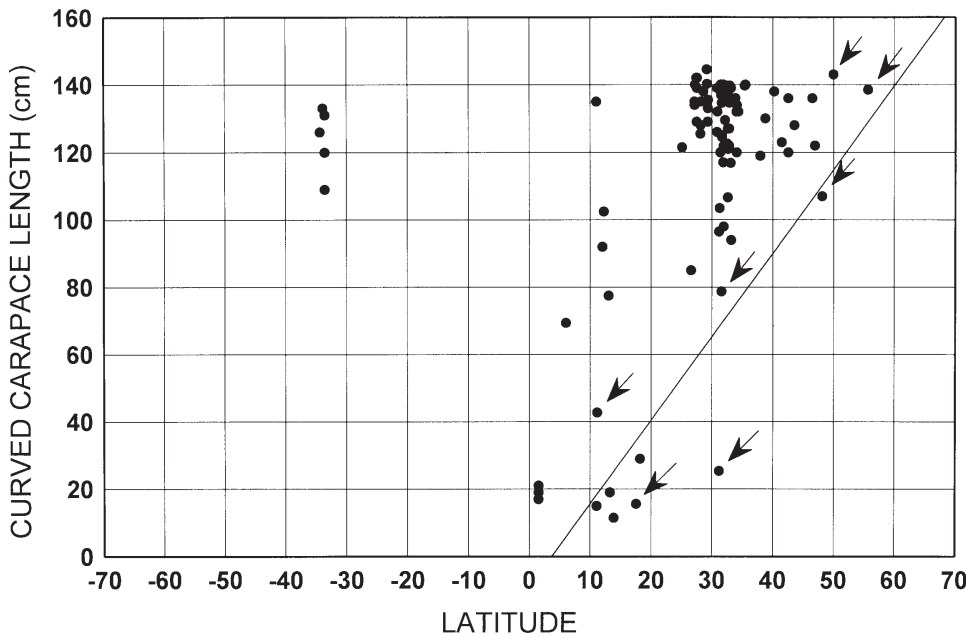

Fig. 2. Dermochelys coriacea. Scatterplot of juvenile sizes compared with latitude of the sighting or stranding. A linear regression was plotted against the highest latitude sighting within each $(20 \mathrm{~cm})$ size class (arrows)

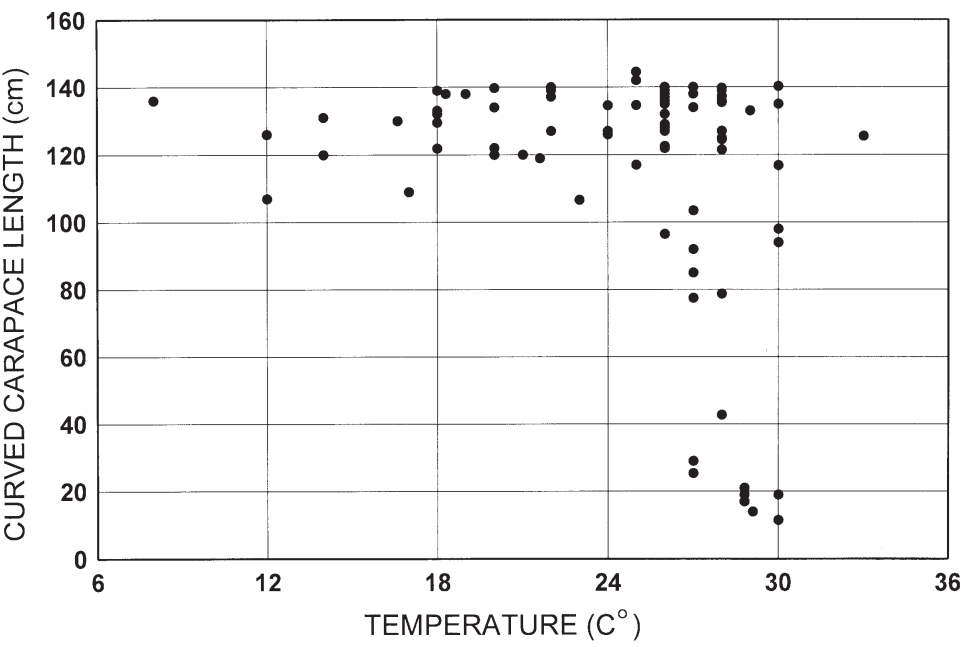

Fig. 3. Dermochelys coriacea. Scatterplot of juvenile sizes compared with surface water temperature at the location of the sighting or stranding

ual (Fig. 3). Rather, there appeared to be a sharp break in the distribution at $100 \mathrm{~cm} \mathrm{CCL}$, with turtles less than $100 \mathrm{~cm}$ found only in waters warmer than $26^{\circ} \mathrm{C}$ and turtles slightly larger than $100 \mathrm{~cm}$ found in waters as cool as $8^{\circ} \mathrm{C}$. While there is a significant $(\mathrm{p}<0.05)$ negative correlation between CCL and temperature, the statistic is weak $(\mathrm{r}=-0.33$,) (Fig. 4).

\section{DISCUSSION}

Leatherbacks have long been considered to be facultative homeotherms capable of maintaining ele- 


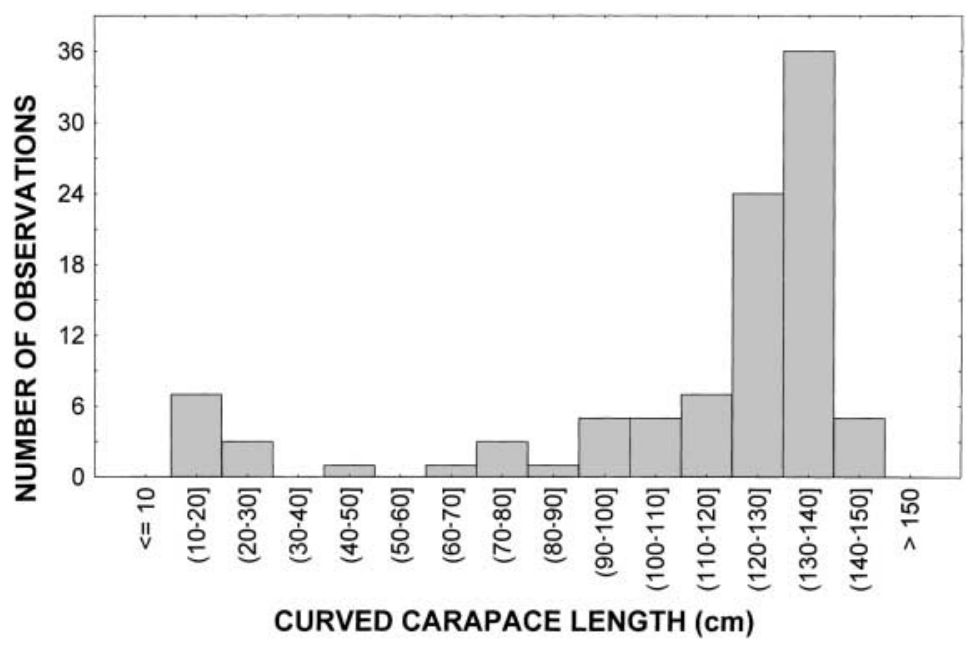

Fig. 4. Dermochelys coriacea. Curved carapace length distribution of sightings utilized in this study. Maximum size was limited to $145 \mathrm{~cm}$ heat metabolically as proposed by Pennick et al. (1998), then the data presented in this paper would imply that this capacity may be developmentally induced, and support the theory that heat generation is physiological rather than simply a function of morphology. At approximately $100 \mathrm{~cm}$ in carapace size there may be an onset of thermogenerating capability which is not found in younger or smaller leatherbacks.

The relationship between the distribution of small leatherbacks and temperature is an important clue to understanding the life history of this unique species. Leatherbacks appear to spend the first portion of their lives in tropical waters. Once they exceed $100 \mathrm{~cm}$ CCL they can move into the cooler waters that have long been considered the primary habitat for the species. vated internal body temperature and thus able to extend their range into cold northern waters (Frair et al. 1972). Morphological and physiological characteristics enhance the leatherbacks' ability to stay warm, including a cylindrical body form, large body mass, thick fatty insulation and countercurrent circulation to reduce heat loss in their extremities (Greer et al. 1973). They are also reported to have temperature independent cellular metabolism (Spotila \& Standora 1985, Paladino et al. 1990, Spotila et al. 1991, Penick et al. 1998).

The restriction of smaller leatherbacks to warmer waters implies that size may play a role in the ability of the species to exist in colder waters. Larger turtles have a larger mass to surface-area ratio and greater thermal inertia which could facilitate living in progressively cooler waters as they grow. Therefore while growth and development are poorly understood in leatherbacks, it would be reasonble to assume that they grow gradually over time, and that this gradual growth would be reflected in a gradual movement of the turtles into cooler waters with increasing size. The positive relationship between turtle size and latitudinal distribution, which is gradual, support this contention if it is assumed that higher latitudes are cooler than lower latitudes. However, the higher latitude sightings of leatherbacks $<100 \mathrm{~cm}$ CCL occurred only where the water temperature was above $26^{\circ} \mathrm{C}$. Further, the relationship between temperature and distribution of juvenile leatherbacks does not support a gradual increase. Rather, there is a distinct transition at $100 \mathrm{~cm}$ CCL, with turtles smaller than this found only in waters of at least $26^{\circ} \mathrm{C}$, and those only slightly larger $(107 \mathrm{~cm})$ found in waters as cold as $12^{\circ} \mathrm{C}$. One explanation for such a rapid transition to a cold-water existence could be developmental. If leatherbacks are able to generate
Acknowledgements. Ann Bowles, Joseph Jehl and 3 anonymous reviewers made helpful suggestions on the manuscript. I am grateful to the following individuals or organizations who provided data for this analysis: George Balazs, Joe Cordero, Christina Fahy, Jacques Fretey, Kelly McAllister, Sally Murphy, Donna Shaver, Margie Stinson, Craig Webster, Brad Winn, and the Burke Museum. The sea surface temperature data were obtained from the NASA Physical Oceanography Distributed Active Archive Center at the Jet Propulsion Laboratory, California Institute of Technology. The work was supported under contract 43 AANF604349 from the Office of Protected Resources, US National Marine Fisheries Service.

\section{LITERATURE CITED}

Acuna AJ, Toledo JR (1994) Rare records of Dermochelys in the Gulf of Venezuela. Mar Turtle Newsl 64:10

Bowen BW, Abreu-Grobois FA, Balazs GH, Kamezaki N, Limpus CJ, Ferl RJ (1995) Trans-pacific migrations of the loggerhead turtle (Caretta caretta) demonstrated with mitochondrial DNA markers. Proc Natl Acad Sci USA 92: 3731-3734

Brongersma LD (1968) Miscellaneous notes on turtles. I. Proc K Ned Akad Wet Ser C Biol Med Sci 71:439-442

Brongersma LD (1969) Miscellaneous notes on turtles. IIA. Proc K Ned Akad Wet Ser C Biol Med Sci 72:76-89

Brongersma LD (1970) Miscellaneous notes on turtles. III. Proc K Ned Akad Wet Ser C Biol Med Sci 73:323-335

Brongersma LD (1972) European Atlantic turtles. Zool Verh (Leiden) 121:1-318

Carr A (1986) Rips, FADS, and little loggerheads. BioScience $36,92-110$

Deraniyagala PEP (1936) The nesting habit of leathery turtle, Dermochelys coriacea. Ceylon J Sci Sect B Zool (19: 331-336

Eckert KL (1993) The biology and population status of marine turtles in the North Pacific Ocean. NOAA Tech Memo NMFS SWFSC 186:155

Frair W, Ackman RG, Mrosovsky N (1972) Body temperature of Dermochelys coriacea: warm turtle from cold water. Science 177:791-793 
Frazier J (1990) Tortugas marinas en Chile. Un Oceano 3:6-7 Grant GS (1994) Juvenile leatherback turtle caught by longline fishing in American Samoa. Mar Turtle Newsl 66: 3-5

Greer AE, Lazell LJD, Wright RM (1973) Anatomical evidence for a countercurrent heat exchanger in the leatherback turtle (Dermochelys coriacea). Nature 244:181

Horrocks JA (1987) Leatherbacks in Barbados. Mar Turtle Newsl 41

Johnson ML (1989) Juvenile leatherback cared for in captivity. Mar Turtle Newsl 47:13-14

McCoy MA (1974) Man and the turtle in the central Carolines. Micronesica 10:207-221

Musick JA, Limpus CJ (1997) Habitat utilization and migration in juvenile sea turtles. In: Lutz PL, Musick JA (eds) The biology of sea turtles. CRC Press Inc., Boca Raton, FL, p 137-163

Paladino FV, O'Connor MP, Spotila JR (1990) Metabolism of leatherback turtles, gigantothermy, and thermoregulation of dinosaurs. Nature 344:858-860

Penick DN, Spotila JR, O'Conner MP, Steyermark AC, George RH, Salice CJ, Paladino FV (1998) Thermal independence of muscle tissue metabolism in the leatherback turtle, Dermochelys coriacea. Comp Biochem Physiol A 120:399-403

Pino JJ, Pino R (1996) Hallazgo de un ejemplar de Der-

Editorial responsibility: Otto Kinne (Editor),

Oldendorf/Luhe, Germany mochelys coriacea en La Playa de Barra, Pontevedra. Bol Biol Asoc Herpetol Esp 7:6

Rhodin AG, Schoelkopf RC (1982) Reproductive data on a female leatherback turtle, Dermochelys coriacea, stranded in New Jersey. Copeia (1982:181-183

Sparks JR (1993) Small juvenile leatherback stranded in St. Lucia. Mar Turtle Newsl 62:9-10

Spotila JR, O'Connor MP, Dodson P, Paladino FV (1991) Hot and cold running dinosaurs: body size, metabolism and migration. Mod Geol 16:203-227

Spotila JR, Standora EA (1985) Environmental constraints on the thermal energetics of sea turtles. Copeia 3:694-702

Standora EA, Spotila JR, Keinath JA, Shoop CR (1984) Body temperatures, diving cycles, and movement of a subadult leatherback turtle, Dermochelys coriacea. Herpetologica 40:169-176

van Dam RP, Diez CE (1998) Home range of immature hawksbill turtles Eretmochelys imbricata at two Caribbean islands. J Exp Mar Biol Ecol 220:15-24

Vazquez J, Perry K, Kilpatrick K (1998) NOAA/NASA AVHRR oceans pathfinder sea surface temperature data set, user's reference manual. Jet Propulsion Laboratory, Pasedina, CA

Walker TA, Parmenter CJ (1990) Absence of a pelagic phase in the life cycle of the flatback turtle, Natator depressa (Garman). J Biogeogr 17:275-278

Submitted: August 9, 2000; Accepted: July 26, 2001 Proofs received from author(s): March 6, 2002 